\title{
Spatial and temporal variations in ammonia emissions - a freely accessible model code for Europe
}

\author{
C. A. Skjøth ${ }^{1}$, C. Geels ${ }^{1}$, H. Berge ${ }^{2}$, S. Gyldenkærne ${ }^{1}$, H. Fagerli ${ }^{2}$, T. Ellermann ${ }^{1}$, L. M. Frohn ${ }^{1}$, J. Christensen ${ }^{1}$, \\ K. M. Hansen ${ }^{1}$, K. Hansen ${ }^{1}$, and O. Hertel ${ }^{1,3}$ \\ ${ }^{1}$ National Environmental Research Institute, Aarhus University, P.O. Box 358, Frederiksborgvej 399, \\ 4000 Roskilde, Denmark \\ ${ }^{2}$ Norwegian Meteorological Institute, P.O. Box 43, 0313 Oslo, Norway \\ ${ }^{3}$ Department for Environmental, Social and Spatial Change (ENSPAC), Roskilde University, P.O. Box 260, Universitetsvej 1, \\ 4000 Roskilde, Denmark
}

Received: 20 November 2010 - Published in Atmos. Chem. Phys. Discuss.: 20 January 2011

Revised: 17 May 2011 - Accepted: 25 May 2011 - Published: 1 June 2011

\begin{abstract}
Deriving a parameterisation of ammonia emissions for use in chemistry-transport models (CTMs) is a complex problem as the emission varies locally as a result of local climate and local agricultural management. In current CTMs such factors are generally not taken into account. This paper demonstrates how local climate and local management can be accounted for in CTMs by applying a modular approach for deriving data as input to a dynamic ammonia emission model for Europe. Default data are obtained from information in the RAINS system, and it is demonstrated how this dynamic emission model based on these input data improves the $\mathrm{NH}_{3}$ calculations in a CTM model when the results are compared with calculations obtained by traditional methods in emission handling. It is also shown how input data can be modified over a specific target region resulting in even further improvement in performance over this domain. The model code and the obtained default values for the modelling experiments are available as supplementary information to this article for use by the modelling community on similar terms as the EMEP CTM model: the GPL licencse v3.
\end{abstract}

\section{Introduction}

Ammonia $\left(\mathrm{NH}_{3}\right)$ plays an important role in the formation of atmospheric aerosols, and its reaction products (ammonium salts) may constitute a significant fraction of the ambient aerosol concentration. This fraction is often in the range of $30 \%$, but it may in some cases be even more than $50 \%$ (Anderson et al., 2003) of the aerosol mass in $\mathrm{PM}_{2.5}$ and $\mathrm{PM}_{10}$.

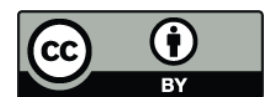

Correspondence to: O. Hertel (ole.hertel@dmu.dk)
More importantly, $\mathrm{NH}_{3}$ plays a significant role in eutrophication of sensitive mainly terrestrial ecosystems (Sutton et al., 2009; Theobald et al., 2009). Agricultural activities are the far dominating sources of $\mathrm{NH}_{3}$ emissions (Bouwman et al., 1997). In the vicinity of intense agricultural activities, deposition of atmospheric $\mathrm{NH}_{3}$ may therefore totally dominate the overall load of reactive nitrogen $(\mathrm{N})$ from the atmosphere (Hertel et al., 2006).

In order to perform high quality assessments of the local $\mathrm{NH}_{3}$ deposition, a high spatial resolution (better than the current $50 \mathrm{~km} \times 50 \mathrm{~km}$ EMEP inventory) in $\mathrm{NH}_{3}$ emissions is crucial (Pul et al., 2004). However, also the temporal resolution plays a very important role. A US study (Gilliland et al., 2003) has shown that even for regional scale assessments of $\mathrm{N}$ deposition, the description of seasonal variation in $\mathrm{NH}_{3}$ emissions may be very important for the model performance, and the results may be improved also when simplified seasonal functions are applied and diurnal variations are disregarded. Similarly, a European study has shown that a high temporal and spatial resolution in nitrogen oxide $\left(\mathrm{NO}_{\mathrm{x}}\right)$ and $\mathrm{NH}_{3}$ emissions is crucial when modelling aerosol concentrations (de Meij et al., 2006). In fact high temporal and spatial resolution in the emission of reactive $\mathrm{N}$ species is considered crucial in modelling policy related reduction strategies (Reis et al., 2009).

Danish studies have shown significant improvements in model performance in regional $\mathrm{N}$ deposition assessments by replacing static seasonal variations by a dynamic approach which is accounting for physical processes like volatilization of $\mathrm{NH}_{3}$ but also for local agricultural production methods including seasonal timing of manure application (Skjøth et al., 2004). This dynamic approach is considered as current state-of-the-art in regional $\mathrm{NH}_{3}$ emission modelling (Hertel

Published by Copernicus Publications on behalf of the European Geosciences Union. 
et al., 2006; Pinder et al., 2006; Zhang et al., 2008) but the requirements for this type of dynamical models are access to detailed information about activity data and the spatial distribution in emissions on annual basis. We have previously shown that this requirement is met in Denmark where it is possible to obtain the necessary input data. The Danish ammonia emission inventory relies on highly detailed national agricultural registers containing exact location of farm houses, storages, and associated fields, as well as data on type and number of livestock, and information about applied production methods (Gyldenkærne et al., 2005; Skjøth et al., 2004). This highly detailed Danish ammonia emission inventory has previously been presented and tested in a CTM. The comparisons between computed and measured ambient $\mathrm{NH}_{3}$ concentrations demonstrated considerable improvements in model performance over Denmark when the high spatial and temporal resolution emission inventory was applied (Skjøth et al., 2004). Despite the improvements obtained by Skjøth et al. (2004) and the recommendations given by Gilliland et al. (2003) and de Meij et al. (2006), simple and generally static methods of relatively coarse resolution are still applied in European regional scale CTMs like the EMEP model (Fagerli and Aas, 2008), CHIMERE (de Meij et al., 2009), TM5 (de Meij et al., 2006), MATCH (Langner et al., 2009) and LOTUS-EUROS (Barbu et al., 2009). Emission inputs to these models are based on emission inventories like EMEP SNAP category level 1 or GENEMIS (Bouwman et al., 1997), that typically distributes the annual emissions applying fixed seasonal variations (see the functions in the EMEP model (Fagerli and Aas, 2008). The reason for these simplifications is most likely that detailed agricultural registers are not generally available in other countries than Denmark. Within the framework of COST ES0602 (Chemical Weather Forecasting) an inter-comparison of air pollution forecast systems in Europe dedicate an entire sub-chapter to this $\mathrm{NH}_{3}$ emission issue (Menut and Bessagnet, 2010). Menut and Bessagnet state that none of the 27 air pollution forecasting systems in Europe contain a temporal profile for ammonia emissions that is sufficiently accurate. Menut and Bessagnet therefore suggest that a dynamical approach of estimating the ammonia emissions should be implemented in these systems (Menut and Bessagnet, 2010). A similar conclusion was presented almost ten years earlier by (Hutchings et al., 2001) and they also stated that a main limitation for such emission models to be successful was the lack of reliable input data. This calls for ways to obtain detailed data alternative to the use of registry data as it is done in Denmark. And in case this is possible to explore the possibility of extending the Danish approach to Europe or even other parts of the world.

Emissions of $\mathrm{NH}_{3}$ from animal waste is a physical process that takes place from wet surfaces (Elzing and Monteny, 1997). It is important to note that organic bound $\mathrm{N}$ in the manure is not a direct source of $\mathrm{NH}_{3}$. The $\mathrm{NH}_{3}$ emission strength is therefore mainly related to the context of TAN
(Total Ammonia $\mathrm{N}\left(\mathrm{NH}_{3}\right.$ and $\left.\mathrm{NH}_{4}^{+}\right)$), $\mathrm{pH}$, temperature, and wind speed. The volatilisation of $\mathrm{NH}_{3}$ is thus highly temperature dependent and varies significantly over day and season (Gyldenkærne et al., 2005; Skjøth et al., 2004). The regional variation reflects local production methods and agricultural practice, which again to a large extent is governed by regional scale climatic conditions. Generalising the Danish approach to other European countries is challenging, because only parts of the necessary information is available at sufficient detail for all countries. Additionally, the available information vary considerably in quality and detail. The model studies by Skjøth et al. (2004) have shown that improving spatial and temporal resolution in emissions in a sub-domain improves the obtained model results inside the sub-domain. Further analysis in connection with the present work has demonstrated that the improvements extend to measurement stations outside but within the vicinity of the high resolution domain. These positive results call for a modular based approach that can handle data of varying degree of detail for different countries and regions in order to obtain the highest spatial and temporal resolution for which reliable information is available and applicable.

The aim of the present paper is thus to present a modular based approach for dynamic $\mathrm{NH}_{3}$ emission modelling on regional scale, and as a part of this work to investigate and describe the available input data on European scale. This is exemplified by applying the approach for the year 2007. The model domain covers central and northern Europe and the results are subsequently implemented in a typical grid based Chemistry-Transport Model (CTM) - in this case the Danish Eulerian Hemispheric Model (DEHM) (Christensen, 1997; Frohn et al., 2002). Computations performed with DEHM are compared with measurements of ambient $\mathrm{NH}_{3}$ concentrations obtained from the EMEP system, where we have included all available stations that are considered representative for their region (not influenced by a single or few nearby $\mathrm{NH}_{3}$ sources).

\section{Methodology}

\subsection{Model domain and meteorological input}

$\mathrm{NH}_{3}$ emissions are simulated using the dynamic model (Gyldenkærne et al., 2005; Skjøth et al., 2004) for a domain covering part of northern and central Europe (Figs. 1, 4 and 5), which corresponds to nest 2 in the DEHM model. The DEHM model domain is over Europe defined using a polar stereographic projection using a regular $96 \times 96$ grid with a $32^{\circ}$ rotation with $50 \mathrm{~km} \times 50 \mathrm{~km}$ grid resolution at $60^{\circ} \mathrm{N}$ (this is a true subset of the EMEP grid http://www.emep.int/ grid/griddescr.html (Fagerli and Aas, 2008)). In the central and northern European region (Fig. 1), where the high resolution $\mathrm{NH}_{3}$ emission model is applied, the sub-domain has a three times higher resolution than the parent grid (Fig. 1) 


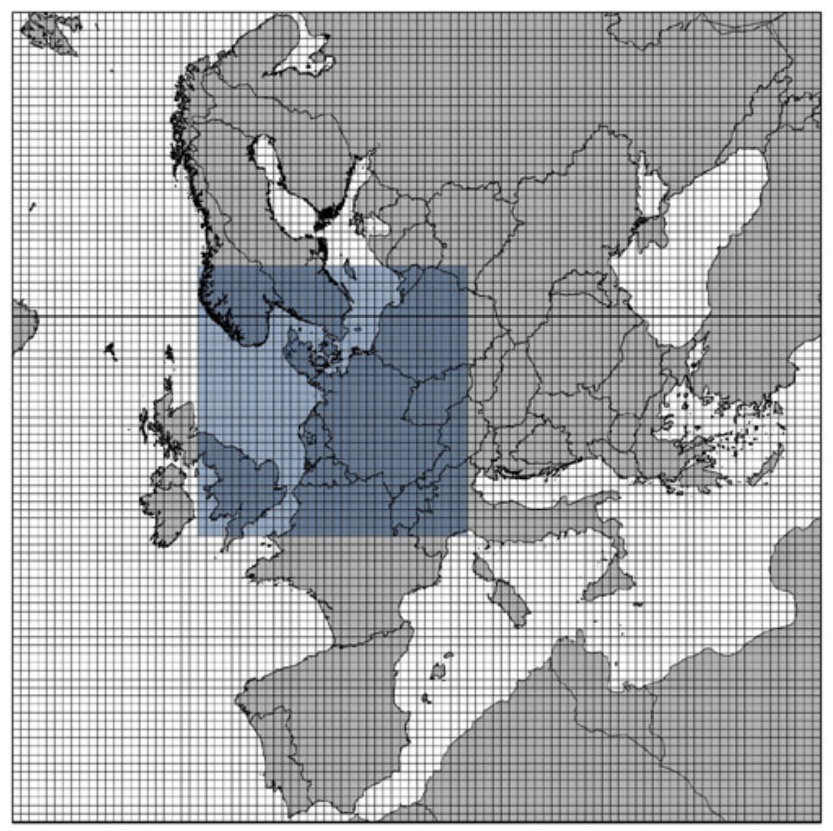

Fig. 1. The applied model grid, which is defined using a polar stereographic projection using a regular $96 \times 96$ grid with a $32^{\circ}$ rotation (this is a true subset of the EMEP grid http://www.emep.int/grid/ griddescr.html (Fagerli and Aas, 2008)). In the Northern European region (the shaded area) the $\mathrm{NH}_{3}$ emission functions are applied for a sub-domain which is defined with a three times higher resolution than the parent grid.

corresponding to a grid resolution of $16.67 \mathrm{~km} \times 16.67 \mathrm{~km}$ at $60^{\circ} \mathrm{N}$. Meteorological input for the $\mathrm{NH}_{3}$ emission model and for the DEHM model have been obtained from the weather forecasting model MM5 (Grell et al., 1994) run with a grid resolution in the domain and sub-domain corresponding to the receptor net in DEHM. The data from the $\mathrm{NH}_{3}$ emission model are generated with a temporal resolution of one hour, are analyzed and afterwards implemented in a typical CTM model: DEHM. The resulting ambient air concentrations are computed with a version of the Danish Eulerian Hemispheric Model (DEHM) (Christensen, 1997; Frohn et al., 2002), which includes two subsequent nests. In this setup, DEHM is a comprehensive CTM including 67 chemical species and a full 3-D description of the lower atmosphere. The model domain covers most of the northern hemisphere with 2 nests with increased resolution over Europe and Northern Europe, where the new dynamic emission inventory is included in the nested domain over northern to central Europe.

\subsection{Measurement data and location of stations}

There are only few locations in the EMEP measurement network from which $\mathrm{NH}_{3}$ measurement data can be obtained from the routine database in the programme. For the current work, measured diurnal mean concentrations of $\mathrm{NH}_{3}$ and $\mathrm{NH}_{\mathrm{x}}$ (the sum of gas phase $\mathrm{NH}_{3}$ and aerosol phase $\mathrm{NH}_{4}^{+}$)

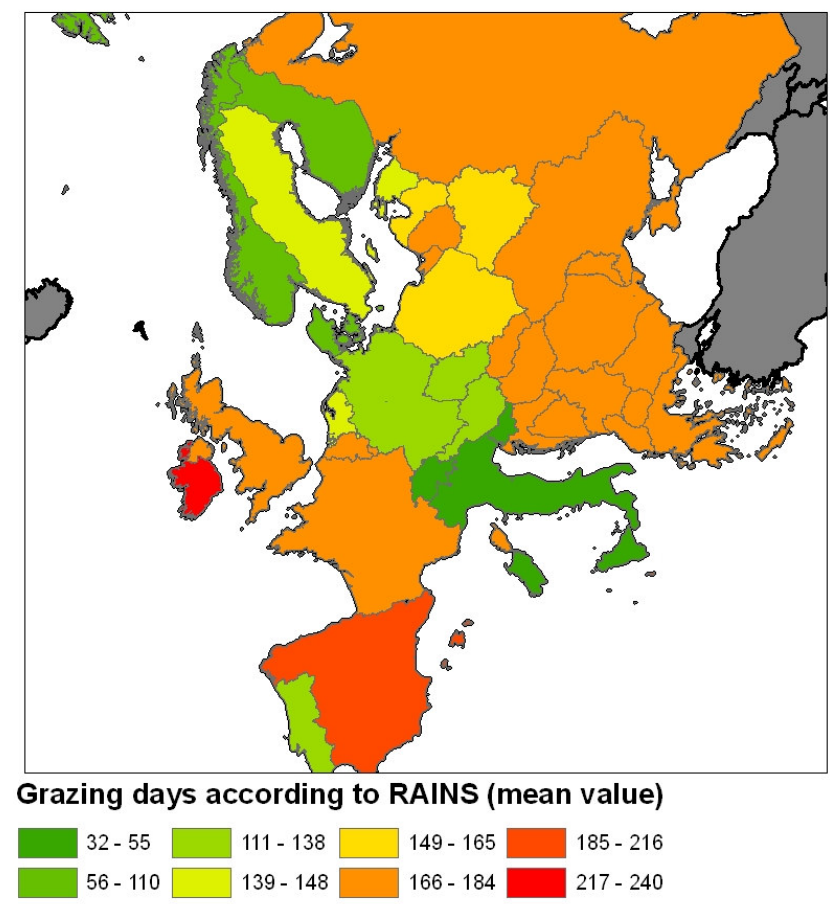

Fig. 2. Number of grazing days for cattle in Europe. Data obtained from the RAINS model work at the IIASA research centre, Vienna, Austria.

have been obtained for the year 2007 at 9 different measurement sites; 5 in Denmark and 4 in Germany (Fig. 3). The stations constitute a mix of beeing located directly in agricultural areas (Ulborg, Tange, Lindet, Neuglosow, Langenbrügge), being coastal stations (Westerland, Keldsnor, Zingst) and one located on an island (Anholt) with very limited husbandry and more than $30 \mathrm{~km}$ to the main land. The measurement station Vreedepeel in the Netherland was also an option in this context, but this station has been disregarded as this site is known to be influenced by very local sources which generally make it difficult to reproduce the observed levels by regional scale CTMs.

The ambient air concentrations are measured using the filter pack method (Ellermann et al., 2009; Skjøth et al., 2008). It is well known that the filter pack method does not give a complete separation of $\mathrm{NH}_{3}$ and $\mathrm{NH}_{4}^{+}$but, comparisons between filter pack and denuder sampling have demonstrated that for Danish monitoring stations a satisfactory separation can be obtained (Andersen and Hovmand, 1994).

\subsection{Temporal variation in $\mathrm{NH}_{3}$ emissions}

The temporal variability of the $\mathrm{NH}_{3}$ emissions is described in 15 additive functions reflecting different agricultural activities. Furthermore a 16th function is included in order to describe the $\mathrm{NH}_{3}$ emissions from traffic. A short description of what is covered by the various functions is given in Table 1. The applied functions were originally derived 


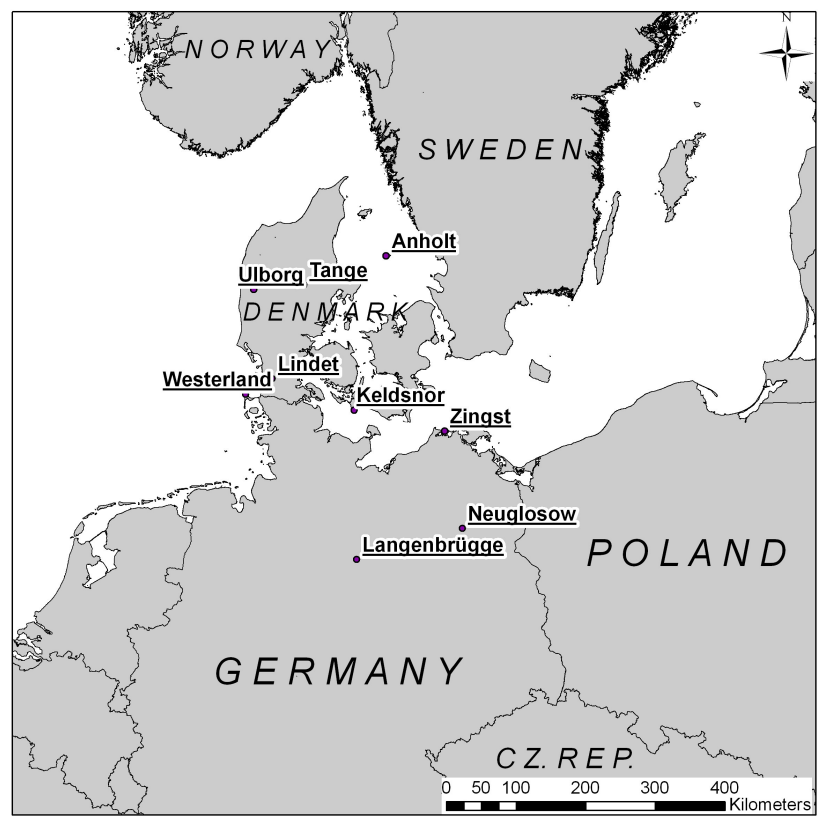

Fig. 3. Measurement stations in Germany and Denmark used in the preliminary validation presented in this paper.

for Danish conditions and presented in Skjøth et al. (2004). However, several of the underlying studies for producing the 15 functions or parameterizations such as the applied growth model (Olesen and Plauborg, 1995) and the farm surveys by Seedorf et al. (1998a; 1998b) are to be considered more general, were the latter are based on European scale studies. This suggests that the functions may be directly applicable for the large parts of the European area. The functions $\left(\mathrm{Fkt}_{1}-\mathrm{Fkt}_{3}\right)$ that are applied for emissions from stables and manure storages are shown in Eq. (1):

$\mathrm{Fkt}_{\mathrm{i}}=\frac{E_{\mathrm{i}}(\mathrm{x}, \mathrm{y})}{\operatorname{Epot}_{\mathrm{i}}(\mathrm{x}, \mathrm{y})} \times\left(T_{\mathrm{i}}(\mathrm{x}, \mathrm{y})\right)^{0.89} \quad \mathrm{i}=[1 ; 3]$

The index i refer to the number of the emission function, where $\mathrm{Fkt}_{1}$ refers to animal houses with forced ventilation, $\mathrm{Fkt}_{2}$ to open animal houses, and $\mathrm{Fkt}_{3}$ to manure storages. The $\mathrm{x}$ and $\mathrm{y}$ refer to the coordinates for the model grid in $\mathrm{x}$ direction and $\mathrm{y}$-direction, respectively. $\mathrm{E}_{\mathrm{i}}(\mathrm{x}, \mathrm{y})$ represents the officially reported annual $\mathrm{NH}_{3}$ emission for the specific grid cell $(\mathrm{x}, \mathrm{y})$; an emission which is identical to the aggregated emission from all categories. Epot $(\mathrm{x}, \mathrm{y})$ is the scaling factor for the emission potential of the grid cell. $T_{\mathrm{i}}(\mathrm{x}, \mathrm{y})$ is the ambient air temperature either inside the animal houses or at the surface of the manure storage. The functions describing the relation between ambient outdoor temperature and temperature in animal houses or manure storages are given in Skjøth et al. (2004).

Emissions of $\mathrm{NH}_{3}$ related to the remaining agricultural activities $\left(\mathrm{Fkt}_{4}-\mathrm{Fkt}_{15}\right)$ are all more or less related to plant growth. Not only direct emissions from plants but also emis-
Table 1. The 16 different functions describing temporal variation in $\mathrm{NH}_{3}$ emissions from various activities; 15 agricultural activities and one related to catalytic converters in personal vehicles.

\begin{tabular}{ll}
$\begin{array}{l}\text { Function } \\
\left(\mathrm{Fkt}_{1}\right.\end{array}$ & \\
$\left.-\mathrm{Fkt}_{16}\right)$ & \\
\hline 1 & Animal houses with forced ventilation \\
2 & Open animal houses (non-forced ventilation) \\
3 & Manure storages \\
4 & Winter crops (no emission simulated in this study) \\
5 & Spring crops (no emission simulated in this study) \\
6 & Late spring crops (no emission simulated in this study) \\
7 & Grass \\
8 & Spring application of manure on bare soil \\
9 & Application of manure on crops \\
10 & Summer application of manure \\
11 & Autumn application of manure \\
12 & Spring application of fertilizer (90\% of all fertilizer) \\
13 & Summer application of fertilizer (10\% of all fertilizer) \\
14 & Emission related to grassing cattle \\
15 & Emissions related to ammonia treated straw \\
16 & Emissions related to personal vehicles with catalytic converters \\
\hline
\end{tabular}

sions due to application of fertilizer and manure can be associated with plant growth, as farmers add fertilizer according to plant need. CTMs are generally grid based, and one single grid cell covers an area that includes many farm houses even for models of high spatial resolution. Farms and farmers that operate in such a domain will not all be active at exactly the same time. This means that the local $\mathrm{NH}_{3}$ emission may be characterized by a statistical distribution and not by short term peak values. Nevertheless the overall emission from each region represented by a grid cell will be affected by the actual meteorological conditions. This statistical distribution will depend on agricultural practice and crop types. The temporal variations for these activities have therefore been parameterized by the gauss functions shown in Eq. (2); where the peaks of the gauss functions are determined by a simple crop growth model:

$$
\begin{gathered}
\mathrm{Fkt}_{\mathrm{i}}=\left(\mathrm{VH} 10_{\text {corr }} \times T_{\text {corr }} \times \frac{\mathrm{E}_{\mathrm{i}}(\mathrm{x}, \mathrm{y})}{\operatorname{Epot}_{\mathrm{i}}(\mathrm{x}, \mathrm{y})}\right) \\
\times \frac{e^{\left(\frac{\left(t-\mu_{i}(\mathrm{x}, \mathrm{y})\right)^{2}}{-2 \sigma_{\mathrm{i}}^{2}(\mathrm{x}, \mathrm{y})}\right)}}{\sigma_{\mathrm{i}} \sqrt{2 \pi}} \quad \mathrm{i}=[4 ; 15]
\end{gathered}
$$

The parameter $\mu_{\mathrm{i}}(\mathrm{x}, \mathrm{y})$ varies from grid cell to grid cell, and it is defined as the time of year when the gauss function reaches its maximum, which again depends on local production methods and type of crops. This parameter is determined using the crop growth model in a preprocessing step, as a function of a temperature sum which again is specific for the activity; the expressions for the temperature sum are given in Skjøth et al. (2004). $\sigma_{i}$ is the spread of the gauss function, where a large value means distribution over most of the year while a small value means that the emission takes place 
Table 2. Distribution of the $\mathrm{NH}_{3}$ emissions on the agricultural activities based on the description in section 2.2 and annual national animal numbers, emission factors etc. from IIASA reviews. The distribution is used to scale gridded total emission inventories into sector based inventories that can be used by formula 1 and 2: the 16 different emission category functions in the emission model (the applied agricultural categories are listed in Table 1).

\begin{tabular}{llllllllllllll}
\hline Name & CU & Fkt $_{1}$ & Fkt $_{2}$ & Fkt $_{3}$ & Fkt $_{8}$ & Fkt $_{9}$ & Fkt $_{10}$ & Fkt $_{11}$ & Fkt $_{11 \mathrm{a}}$ & Fkt $_{12}$ & Fkt $_{13}$ & Fkt $_{14}$ & Fkt $_{15}$ \\
\hline Austria & AT & 0.23 & 0.11 & 0.16 & 0.07 & 0.07 & 0.07 & 0.06 & 0.06 & 0.06 & 0.01 & 0.10 & 0.01 \\
Belgium & $\mathrm{BE}$ & 0.32 & 0.09 & 0.04 & 0.07 & 0.07 & 0.07 & 0.06 & 0.06 & 0.04 & 0.00 & 0.09 & 0.07 \\
Belarus & $\mathrm{BY}$ & 0.20 & 0.09 & 0.07 & 0.09 & 0.09 & 0.00 & 0.05 & 0.05 & 0.28 & 0.03 & 0.05 & 0.01 \\
Switzerland & $\mathrm{CH}$ & 0.11 & 0.14 & 0.11 & 0.05 & 0.05 & 0.19 & 0.09 & 0.09 & 0.08 & 0.01 & 0.04 & 0.03 \\
Czech Republic & $\mathrm{CZ}$ & 0.22 & 0.05 & 0.10 & 0.10 & 0.10 & 0.01 & 0.05 & 0.05 & 0.20 & 0.02 & 0.06 & 0.03 \\
Denmark & $\mathrm{DK}$ & 0.26 & 0.06 & 0.14 & 0.14 & 0.14 & 0.05 & 0.06 & 0.06 & 0.06 & 0.01 & 0.03 & 0.01 \\
Germany & FGD & 0.19 & 0.08 & 0.18 & 0.10 & 0.10 & 0.02 & 0.06 & 0.06 & 0.15 & 0.02 & 0.03 & 0.02 \\
France & FR & 0.17 & 0.07 & 0.11 & 0.07 & 0.07 & 0.07 & 0.06 & 0.06 & 0.20 & 0.02 & 0.09 & 0.01 \\
United Kingdom & GB & 0.07 & 0.13 & 0.10 & 0.05 & 0.05 & 0.03 & 0.03 & 0.03 & 0.38 & 0.04 & 0.04 & 0.05 \\
Italy & IT & 0.11 & 0.05 & 0.21 & 0.11 & 0.11 & 0.02 & 0.06 & 0.06 & 0.21 & 0.02 & 0.03 & 0.00 \\
Lithuania & LT & 0.07 & 0.07 & 0.06 & 0.03 & 0.03 & 0.03 & 0.03 & 0.03 & 0.39 & 0.04 & 0.05 & 0.16 \\
Netherlands & NL & 0.20 & 0.10 & 0.12 & 0.11 & 0.11 & 0.09 & 0.08 & 0.08 & 0.04 & 0.00 & 0.05 & 0.03 \\
Norway & NO & 0.15 & 0.15 & 0.17 & 0.09 & 0.09 & 0.06 & 0.07 & 0.07 & 0.04 & 0.00 & 0.11 & 0.01 \\
Poland & PL & 0.20 & 0.09 & 0.07 & 0.09 & 0.09 & 0.00 & 0.05 & 0.05 & 0.28 & 0.03 & 0.05 & 0.01 \\
Kaliningrad & RUA & 0.20 & 0.09 & 0.07 & 0.09 & 0.09 & 0.00 & 0.05 & 0.05 & 0.28 & 0.03 & 0.05 & 0.01 \\
Sweden & SE & 0.15 & 0.15 & 0.17 & 0.09 & 0.09 & 0.06 & 0.07 & 0.07 & 0.04 & 0.00 & 0.11 & 0.01 \\
Slovakia & SK & 0.22 & 0.05 & 0.10 & 0.10 & 0.10 & 0.01 & 0.05 & 0.05 & 0.20 & 0.02 & 0.06 & 0.03 \\
\hline
\end{tabular}

during a short time period. $\mathrm{VH} 10_{\text {corr }}$ and $T_{\text {corr }}$ are given by Eq. (8) in Gyldenkærne et al. (2005).

\subsection{Country wide data regarding agricultural emissions}

The distribution of the $\mathrm{NH}_{3}$ emissions on the agricultural activities has been derived from national information about type and number of livestock, number of grazing days for the cattle (see the European distribution in Fig. 2), specific emission factors, and local meteorology etc. This data has to a large extent been based on information from the database collected in relation to the RAINS model and especially a dedicated ammonia emission review (Klimont and Brink, 2004). The RAINS model database contains information e.g. about the number of livestock of each animal type in the European countries, national emission factors for each animal type, data regarding arable land and grass land. The national reports contain information about the fraction of the manure that is applied to crops in growth or permanent grass land. It is here assumed that areas with growing crops receive manure from livestock in spring or autumn. Similarly it is assumed that permanent grass land receives manure in spring, summer and autumn. The resulting relative distribution of ammonia emission between the 15 additive functions is given in Table 2 on country basis. Table 2 has afterwards been gridded to the DEHM sub-domain on $16.67 \mathrm{~km} \times 16.67 \mathrm{~km}$ grid resolution and combined with the emission inventory given by Hertel et al. (2002). This table is the default data set supplied by the model. Model calculations with this dataset are in the following termed "de- fault". Additionally the distribution among the 15 additive functions from the paper by Skjøth et al. (2008) has been applied specifically over the Danish area in order to demonstrate that it is possible to improve the model input data over a specific target region. Model calculations with this data set are termed "dk_improved". Model calculations with the traditional $\mathrm{NH}_{3}$ emission methodology using static functions are termed "old".

\section{Results}

\subsection{The obtained emission inventory}

In Table 2 country wise $\mathrm{NH}_{3}$ emission distributions have been listed for the specific agricultural emission categories that are represented by the 15 functions. A gridded data set has been derived for the entire model domain (Fig. 1). It is evident that even for central or northern Europe there are differences in agricultural practice that lead to significant differences between the countries. One example is that some countries use vast amounts of mineral fertilizer (this is e.g. the case for the Czech Republic, Poland and France), while other countries use relatively small amounts (this is the case for countries like Denmark and Norway) (see Fkt 12 and $\mathrm{Fkt}_{13}$ in Table 2). Another example is from the variation in emissions related to animal production $\left(\mathrm{Fkt}_{1}\right.$ and $\left.\mathrm{Fkt}_{2}\right)$. Pigs are the dominating part of the livestock production in Denmark leading to $\mathrm{Fkt}_{1}$ and $\mathrm{Fkt}_{2}$ values of 0.26 and 0.06 , whereas the similar values for Norway are 0.15 and 0.15 due 


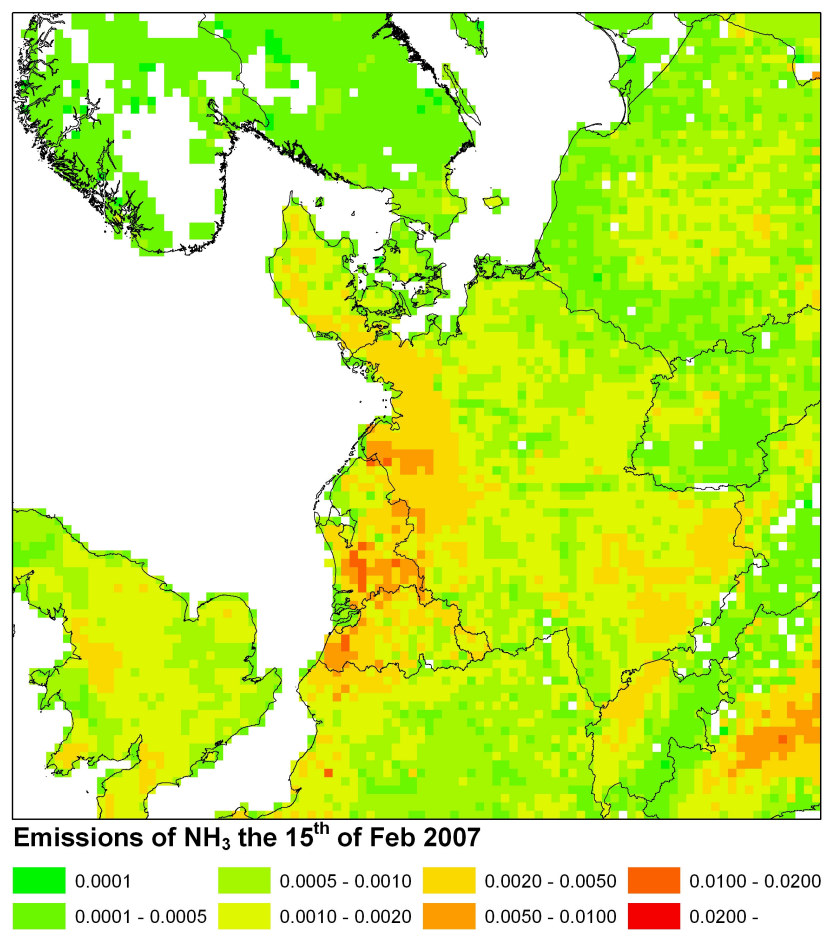

Fig. 4. The computed spatial distribution in $\mathrm{NH}_{3}$ emissions over Europe produced from the dynamic emission model for 15 February 2007 at 12:00 UTC. The emissions are given in kTonnes $\mathrm{N} / 16.67 \mathrm{~km} \times 16.67 \mathrm{~km} \mathrm{~h}^{-1}$.

to a more evenly distribution between pigs and cattle in this country. This difference affects the overall emission profile since the temperature in pig barns is much higher compared with cattle barns.

The relative distribution in $\mathrm{NH}_{3}$ emissions has in total been derived for 11 agricultural emission categories, and the obtained values are listed country by country in Table 2 . The remaining four agricultural categories (relating to the dynamic emission functions $\mathrm{Fkt}_{4}$ to $\mathrm{Fkt}_{7}$ ) are related to emissions from crops, and have been disregarded due to insufficient available information. In the distribution it has been assumed that manure application is equally split between spring and autumn application, whereas the application of mineral fertiliser has been distributed with $90 \%$ in spring and only $10 \%$ in autumn. Application of manure to grass land has been assumed to take place evenly distributed on all application periods. Furthermore it is assumed that solid manure from cattle is applied on black soil (Gyldenkærne et al., 2005), whereas liquid slurry from pigs is applied on growing crops (Gyldenkærne et al., 2005).

\subsection{Simulated ammonia emissions: gridded and as time series}

Figures 4 and 5 show the obtained spatial distributions of $\mathrm{NH}_{3}$ emissions for Europe computed for 12:00 UTC, the

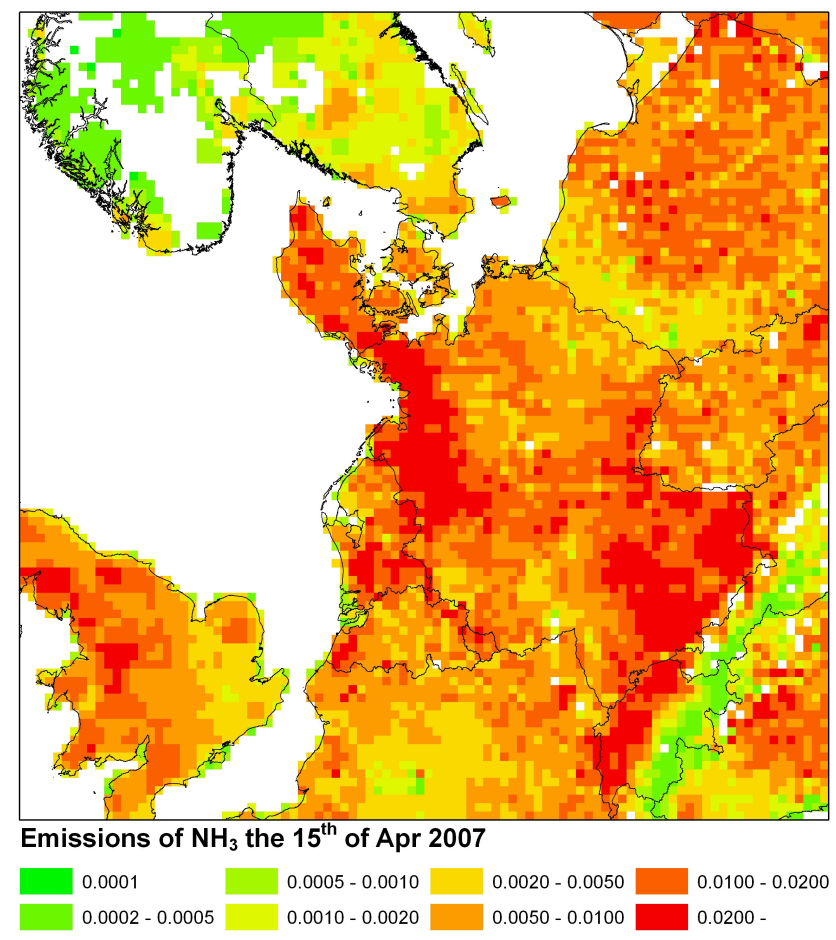

Fig. 5. The computed spatial distribution in $\mathrm{NH}_{3}$ emissions over Europe produced from the dynamic emission model for 15 April 2007 at 12:00 UTC. The emissions are given in $\mathrm{k}$ Tonnes $\mathrm{N} / 16.67 \mathrm{~km} \times 16.67 \mathrm{~km} \mathrm{~h}^{-1}$.

15 February and 15 April 2007, respectively. In February the highest $\mathrm{NH}_{3}$ emissions are seen in Belgium, the Netherlands and in the Po Valley in Italy (Fig. 4). High emissions are also found in southern Germany, north and north-western Germany as well as in parts of Denmark and the UK. In contrast very low emissions are found in Norway, Sweden and parts of the Alpine region. In April (Fig. 5) highest emission areas are found in southern Germany, northern Germany, parts of Netherlands, UK and Denmark. Low emissions are still found in Norway, Sweden and the Alpine region. Large areas of France, the Po Valey in Italy and the region between Germany and Poland are characterized by medium to high emissions in mid-April.

Figure 8 shows the modelled hourly $\mathrm{NH}_{3}$ emission time series from the German monitoring site Zingst in 2007. Results are plotted on sector basis for each of the applied functions. In winter, emissions are generally low and the main contributions are from pig housings $\left(\mathrm{Fkt}_{1}\right)$ and storage $\left(\mathrm{Fkt}_{3}\right)$. Rapid increase in the emission is seen in early March, and the emission peaks during the first weeks of April. This increase is related to manure application on bare soil (Fkt 8 ), liquid manure application to growing crops $\left(\mathrm{Fkt}_{9}\right)$, and mineral fertilizer applied to growing crops $\left(\mathrm{Fkt}_{12}\right)$. Summer emissions are a factor of two higher than in winter emissions, but significantly lower than during the spring. The difference between summer and winter is a result of a higher "base 


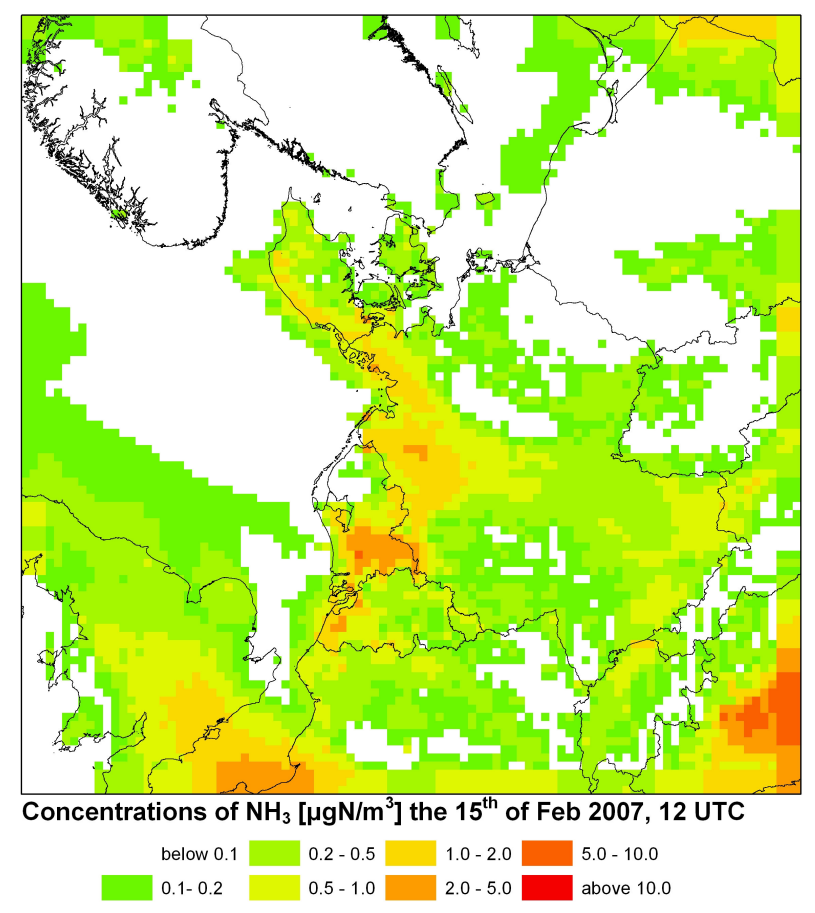

Fig. 6. The computed spatial distribution in ambient air $\mathrm{NH}_{3}$ concentrations over Europe from the DEHM model for 15 February 2007.

load" from cattle barns ( $\left.\mathrm{Fkt}_{2}\right)$, grazing cattle ( $\left.\mathrm{Fkt}_{14}\right)$, storage $\left(\mathrm{Fkt}_{3}\right)$, and a number of summer applications of manure on growing grass $\left(\mathrm{Fkt}_{10}\right.$ and $\left.\mathrm{Fkt}_{13}\right)$. An increase in emissions from summer to autumn is related to an autumn application on land covered by vegetation $\left(\mathrm{Fkt}_{11 \mathrm{a}}\right)$ and emptying of storage facilities $\left(\mathrm{Fkt}_{11 \mathrm{~b}}\right)$. It is evident that emissions from pig barns $\left(\mathrm{Fkt}_{1}\right)$ show very little variation over season as well as over the day. This is in strong contrast to manure applied to growing crops (Fkt9) and application of mineral fertilizer $\left(\mathrm{Fkt}_{2}\right)$, which is present only in a limited number of days and in addition show a strong diurnal profile. The overall emission temporal emission profile for Zingst can also be seen in Fig. 8 (bottom) as a time series and correspondingly for Tange and Westerland in Fig. 9. The Danish station Tange has a very low winter level, a steep increase in the emission during the spring and a moderate summer level. Westerland has a low winter level, a steep spring emission and an additional large peak during autum. Figure 10 provides a comparison of the total modelled emission pattern in spring 2007 for three different monitoring sites in the domain: Tange in central Denmark, Langebrügge, and Neuglobsow in Germany. Tange shows the overall highest emission, which during the period 1 to 20 March is about 2 to 3 times higher than for the two other sites. During 20 March to 4 April, the emissions at Tange and Langebrügge are in the same range and showing large day to night variations due to daily variations in temperature and wind speed at the selected sites.

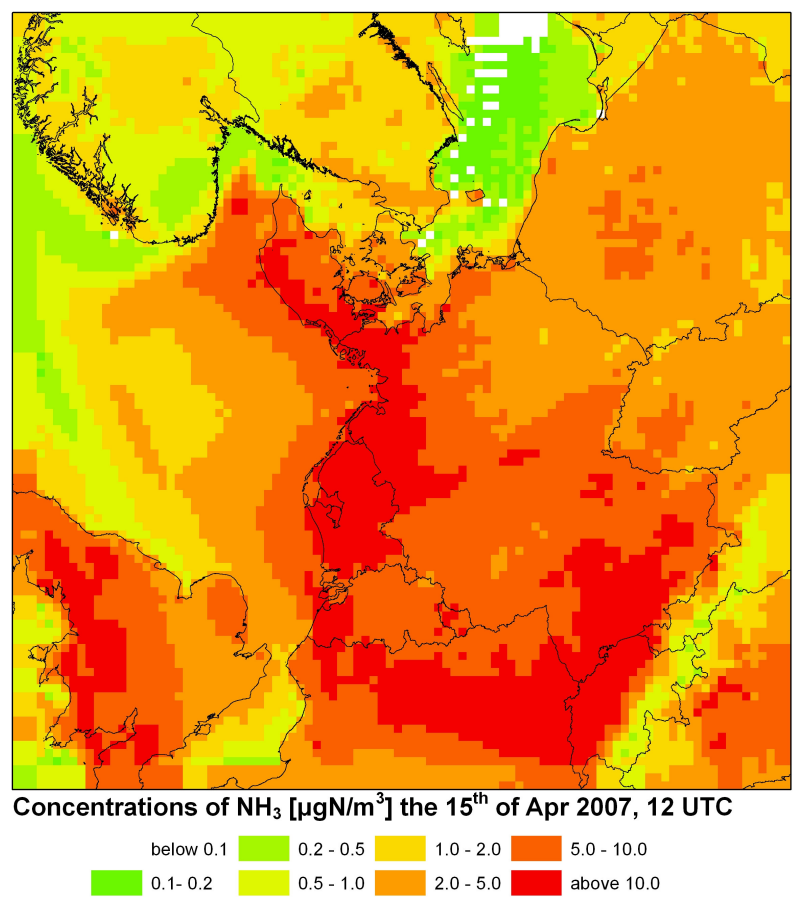

Fig. 7. The computed spatial distribution in ambient air $\mathrm{NH}_{3}$ concentrations over Europe from the DEHM model for 15 April 2007.

\subsection{Simulated ambient concentrations and comparisons to measurements}

Figures 6 and 7 show the calculated $\mathrm{NH}_{3}$ concentrations with DEHM by using the dk_improved scenario at 12:00 UTC, the 15 February and 15 April 2007, respectively. In February the highest $\mathrm{NH}_{3}$ concentrations are seen in the Netherlands and in the Po Valley in Italy (Fig. 6). High concentrations are also found in Northwestern Germany and parts of France. Very low concentrations are found in almost all countries north of the Alpine region as well as sea areas. In April (Fig. 7) highest concentrations areas are found in Germany, Netherlands, UK and parts of France and Denmark. Low concentrations are still found in Norway, Sweden and the Alpine region. Poland and the Po Valley in Italy and the eastern part of Germany and Poland are characterized by medium to high concentrations. Additionally a gradient going from the land areas and into the North Sea is evident, especially from Denmark, the Netherlands and northern Germany.

$\mathrm{NH}_{3}$ concentrations obtained from DEHM calculations performed for the three scenarios are shown as time series in Figs. 8 and 9, and obtained correlation coefficients and bias for $\mathrm{NH}_{3}$ and $\mathrm{NH}_{\mathrm{x}}$ for each of the 9 stations are shown in Tables 3 and 4 on annual and seasonal basis. The results in Table 3 show that the default scenario improves the correlation between observed and modeled daily $\mathrm{NH}_{3}$ concentrations for all sites, where some of the improvements are substantial (e.g the correlation coefficient improves from 

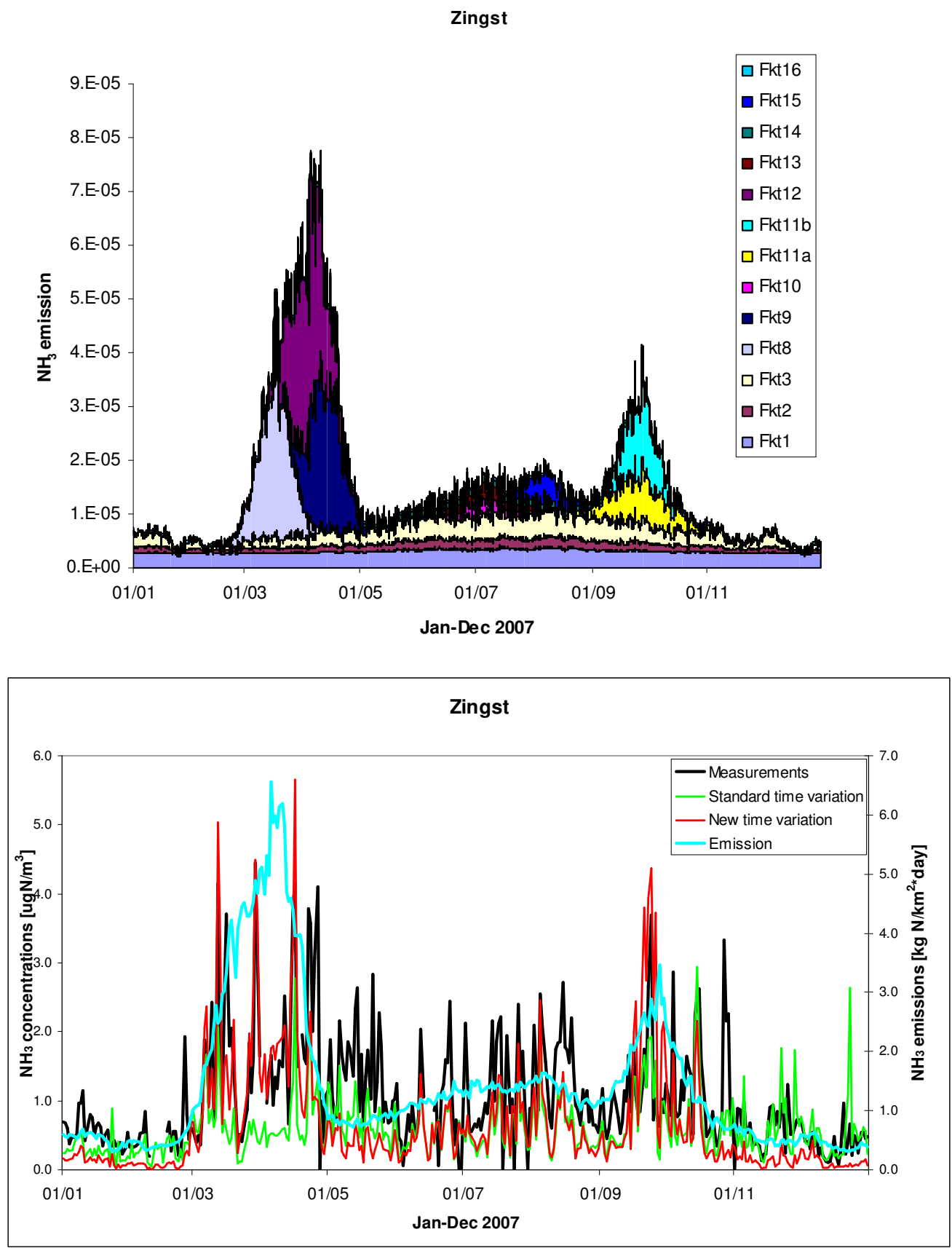

Fig. 8. Upper figure shows time series for the seasonal variation in emissions for the various agricultural emission categories. Lower figure shows a comparison between modelled and measured $\mathrm{NH}_{3}$ ambient air concentrations in 2007 for the German site Zingst. Model calculations are performed with DEHM using the traditional emission calculation methodology (old) and the new dynamic $\mathrm{NH}_{3}$ emission model (dk_improved), where the resulting emission profile for the latter is also shown.

0.27 and up to 0.61 for Neuglobsow). Additional large improvements are seen for the Danish stations and Westerland for the "dk_improved" scenario. On seasonal basis improvements in the correlation coefficients are mainly seen during spring and summer. The bias is low for most of the stations and most of the seasons, except for winter, where the model underestimates the concentrations at almost all sites for all scenarios.

The default scenario improves the correlation coefficient between the observed and modeled $\mathrm{NH}_{\mathrm{x}}$ concentrations at two sites and a decrease in performance at 7 sites, where all changes are in the range 0.02 to 0.12 ) except for Neuglobsow, 

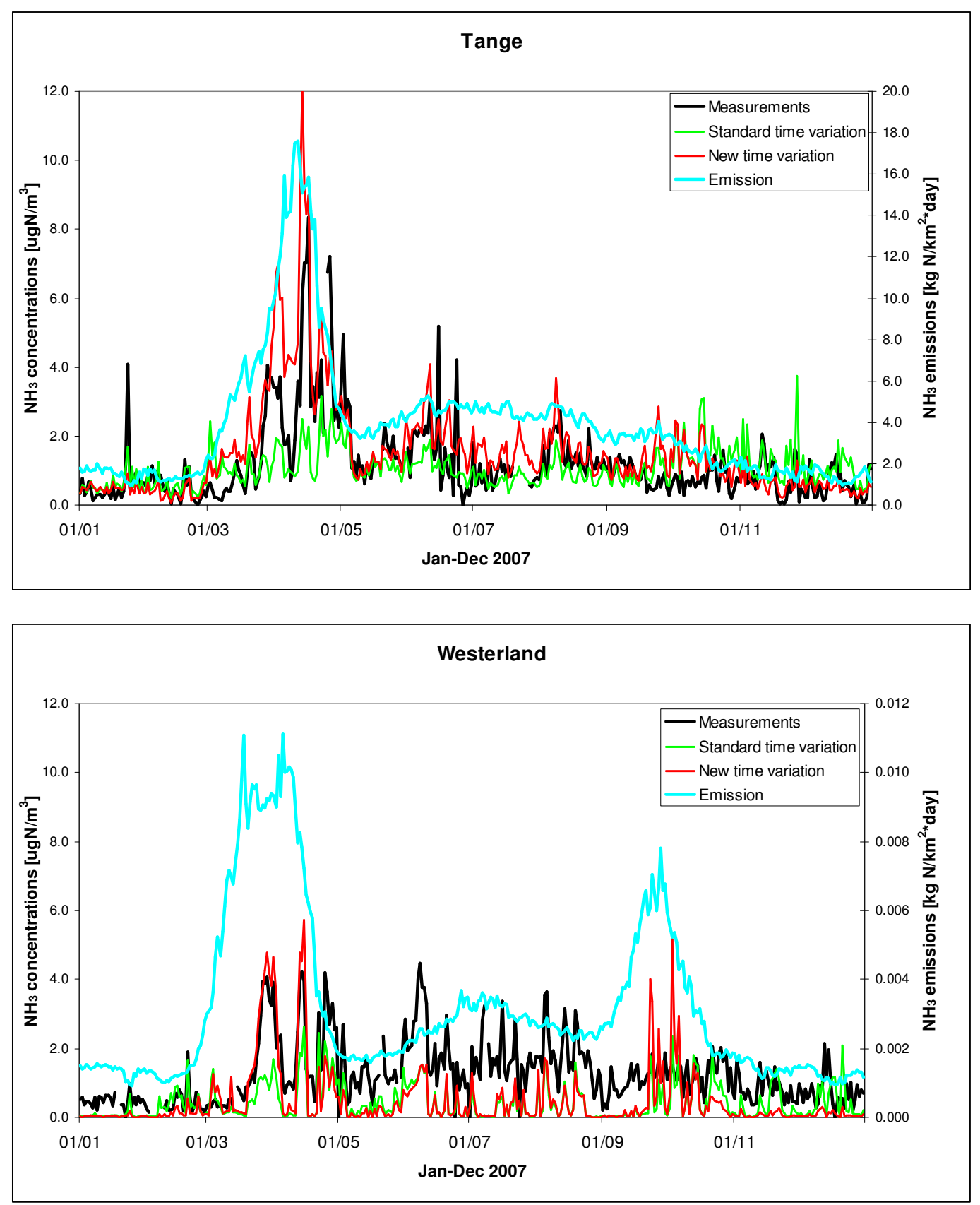

Fig. 9. Comparison between modelled and measured $\mathrm{NH}_{3}$ ambient air concentrations in 2007 for the German site Westerland (lower figure) and the Danish site Tange (upper figure). Model calculations are performed with DEHM using the traditional emission calculation methodology (old) and the new dynamic $\mathrm{NH}_{3}$ emission model (dk_improved), where the resulting emission profile for the latter is also shown.

where the improvement is 0.15 . The "dk_improved" scenario improves the correlation coefficient for the Danish stations and Westerland. Five out of six stations had an improvement from 0.04 and up to 0.15 whereas the obtained correlation coefficient for Keldsnor decreases slightly from 0.55 to 0.54 .
The concentration time series for Westerland (Fig. 9) show similar results to what is obtained for Zingst, except that the emission pattern in spring (March to May) shows a less pronounced peak than what was obtained for Zingst (Fig. 8).

The $\mathrm{NH}_{3}$ concentration time series for Tange, Westerland and Zingst are shown for the "dk_improved" scenario. The seasonal variation is strongly enhanced at Zingst (Fig. 8) 
Table 3. Correlation coefficients, observed mean and modelled bias between measured and modelled $\mathrm{NH}_{3}$ before and after implementation of the new dynamic $\mathrm{NH}_{3}$ emission inventory for northern Europe. Two steps have been used in the implementation of the new dynamic emission model. In the first step, data (new) from the RAINS model have been used to distribute the national emissions in each grid cell of the high resolution domain. In the second step (dk), the previously presented detailed Danish emission distribution on the 15 emission functions presented in Table 1 in (Skjøth et al., 2004; Skjøth et al., 2008) has been implemented as a supplement to the RAINS data. Calculations performed with the DEHM model for the year 2007.

\begin{tabular}{|c|c|c|c|c|c|c|c|c|c|c|c|}
\hline & \multicolumn{6}{|c|}{ Correlation coefficient } & \multicolumn{5}{|c|}{ Mean meas. concentration $\left[\mu \mathrm{g} \mathrm{m}^{-3}\right]$, Bias $\left[\mu \mathrm{g} \mathrm{m}^{-3}\right]$} \\
\hline & type & year & winter & spring & summer & autumn & year & winter & spring & summer & autumn \\
\hline \multirow{2}{*}{ Zingst } & old & 0.61 & 0.18 & 0.61 & 0.73 & 0.61 & $1.06,-0.45$ & $0.48,-0.10$ & $1.60,-0.87$ & $1.11,-0.53$ & $1.00,-0.29$ \\
\hline & Dk & 0.68 & 0.43 & 0.66 & 0.71 & 0.56 & -0.39 & -0.35 & -0.44 & -0.49 & -0.30 \\
\hline \multirow[b]{2}{*}{ Langenbrugge } & old & 0.37 & -0.03 & 0.38 & 0.54 & 0.15 & $1.29,0.24$ & $0.66,0.44$ & $1.89,0.03$ & $1.59,-0.24$ & $1.04,0.73$ \\
\hline & new & 0.48 & 0.18 & 0.21 & 0.49 & 0.59 & 0.47 & -0.25 & 1.56 & -0.15 & 0.67 \\
\hline \multirow{3}{*}{ Westerland } & old & 0.59 & 0.25 & 0.77 & 0.74 & 0.51 & $1.26,-0.82$ & $0.57,-0.27$ & $1.52,-0.93$ & $1.82,-1.41$ & $1.05,-0.60$ \\
\hline & new & 0.62 & 0.32 & 0.79 & 0.71 & 0.41 & -0.75 & -0.49 & -0.51 & -1.39 & -0.58 \\
\hline & $\mathrm{Dk}$ & 0.69 & 0.34 & 0.81 & 0.74 & 0.41 & -0.74 & -0.49 & -0.43 & -1.30 & -0.70 \\
\hline \multirow{3}{*}{ Neuglobsow } & old & 0.27 & -0.16 & 0.04 & 0.29 & 0.23 & $0.84,0.14$ & $0.32,0.36$ & $1.46,-0.23$ & $0.88,0.01$ & $0.67,0.45$ \\
\hline & new & 0.61 & 0.44 & 0.39 & 0.17 & 0.66 & 0.37 & -0.07 & 1.00 & 0.09 & 0.46 \\
\hline & Dk & 0.60 & 0.38 & 0.37 & 0.17 & 0.62 & 0.31 & -0.11 & 0.85 & 0.07 & 0.44 \\
\hline \multirow{3}{*}{ Keldsnor* } & old & 0.41 & 0.31 & 0.47 & 0.52 & 0.26 & $0.54,0.12$ & $0.20,0.21$ & $0.83,-0.08$ & $0.47,0.15$ & $0.61,0.20$ \\
\hline & new & 0.44 & 0.47 & 0.57 & 0.41 & 0.14 & 0.14 & -0.03 & 0.17 & 0.16 & 0.22 \\
\hline & Dk & 0.51 & 0.51 & 0.67 & 0.41 & 0.19 & 0.14 & -0.02 & 0.20 & 0.28 & 0.08 \\
\hline \multirow{3}{*}{ Lindet } & old & 0.39 & 0.49 & 0.34 & 0.55 & 0.60 & $1.14,0.02$ & $0.68,0.19$ & $1.67,-0.38$ & $1.47,-0.42$ & $0.97,0.45$ \\
\hline & new & 0.55 & 0.33 & 0.63 & 0.56 & 0.26 & 0.36 & -0.14 & 0.92 & -0.07 & 0.69 \\
\hline & Dk & 0.71 & 0.38 & 0.76 & 0.59 & 0.42 & 0.28 & -0.13 & 0.78 & 0.41 & 0.19 \\
\hline \multirow{3}{*}{ Tange } & old & 0.46 & 0.55 & 0.57 & 0.56 & 0.10 & $1.20,-0.14$ & $0.55,0.16$ & $2.14,-0.84$ & $1.32,-0.37$ & $0.81,0.46$ \\
\hline & new & 0.55 & 0.45 & 0.58 & 0.38 & -0.10 & 0.32 & -0.13 & 0.55 & -0.01 & 0.85 \\
\hline & Dk & 0.77 & 0.50 & 0.76 & 0.51 & 0.05 & 0.33 & -0.11 & 0.78 & 0.42 & 0.26 \\
\hline Ulborg & old & 0.60 & 0.61 & 0.72 & 0.83 & 0.56 & $0.65,0.69$ & $0.18,0.82$ & $1.27,0.36$ & $0.79,0.40$ & $0.44,1.15$ \\
\hline
\end{tabular}

* At Keldsnor measured values from three days in October 2007 have been excluded here as they were unusual high and probably represented very local emissions.

with the new parameterization, especially in the spring season. During summer there are very small variations between the old and the new methodology. During mid summer and during winter the concentrations are underestimated. Similar improvements are seen for the Tange station (Fig. 9) and at this site the simulated winter and summer concentrations are at the same level as the measurements. For the Westerland site the performance the model predicts zero concentrations in periods where the measurements are in general very low and also during several periods during the summer where the measurements show concentrations of several ppb. During spring from March to May the model calculations are improved significantly at the Westerland site.
Figure 11 shows four different scatter plots comparing measured and modeled $\mathrm{NH}_{3}$ concentrations for the selected German and Danish measurement sites and using the original and the new emission parameterization (dk_improved scenario). For the Danish stations the improvements are very visible in the scatter plot and more pronounced than for the German stations, and this is reflected in the large increase in correlation coefficients in Table 3 .

\section{Discussion}

The modular approach used in the presented dynamic emission model allows for regional calibration of local agricultural practice such as how much time the livestock are allowed to graze on the fields; information which in this case 
Simulated emission of ammonia during March-April 2007

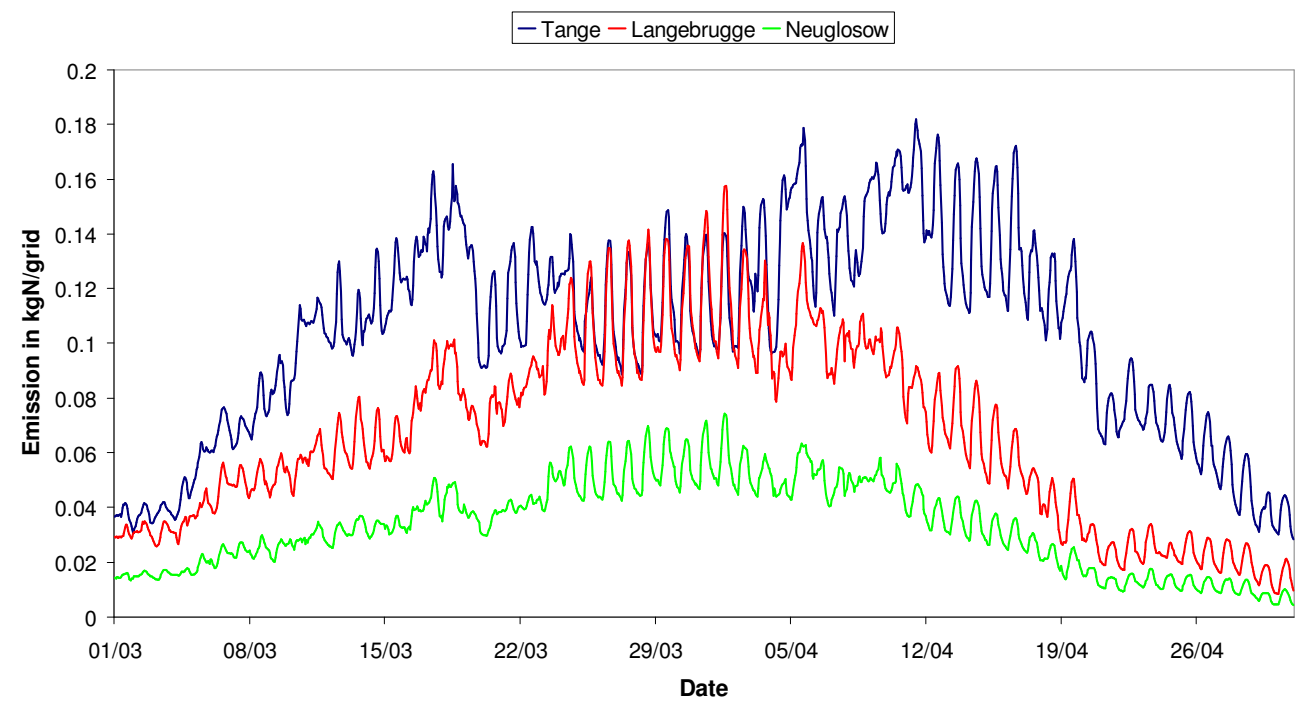

Fig. 10. The hourly variation in simulated $\mathrm{NH}_{3}$ emissions from the dynamic emission model. Data are shown for March to April 2007 for the Danish site Tange and for the two German Sites: Langebrügge and Neuglosow.

is obtained from RAINS data (Fig. 2), how the emission from fertilizer is distributed among specific application times in case default values are used (Table 3 ) and how specific target areas can be improved by using more detailed information than the RAINS systems such as Table 1 by Skjøth et al. (2008). The dynamical model produces large variations in diurnal $\mathrm{NH}_{3}$ emission patterns (Figs. 8, 9 and 10), which is primarily related to variations in meteorology affecting the volatilization of $\mathrm{NH}_{3}$. The emission model accounts for the north-south gradients that are related to differences in growth season which again is affecting the timing of manure application: Southern regions have an earlier spring peak than more northerly regions (see e.g. Supplement).

The dynamic model in general captures the observed low values in winter and the steep increase in $\mathrm{NH}_{3}$ emissions during spring, which is mainly due to the spring application of manure and mineral fertilizer. However, the model tends to overestimate the extremes in the emission pattern, especially for the spring peak. This means that the model results have a larger seasonal variation compared to the old method. This variation do to some degree fits the overall seasonal measured values. Such changes can be seen by an increase in correlation coefficient and at the same time an increase in bias at some stations. This overestimation might be related to the fact, that the model assumes that application of manure takes a certain amount of time in each grid cell and that this amount of time is calibrated against Danish production methods (Skjøth et al., 2004). It is likely, that farmers outside Denmark spends more time on applying manure and fertilizer than the Danish farmers. This can be taken into account by the model by increasing the factor $\sigma_{\mathrm{i}}$ in Eq. (2). The preliminary validations show that the model is leading to underes- timation in winter and mid summer whereas some overestimation is found for the spring peak. The overall increase in performance of $\mathrm{NH}_{3}$ concentrations when the dynamic emission model is implemented for central and northern Europe is considerably lower than what was found in the validation of the implementation for Denmark (Skjøth et al., 2004). This is clearly seen in Table 3, where the highest correlations are found for the Danish stations and the lowest for the German stations. This is likely a result of a variety of uncertainties in the assumptions, and especially in the underlying input data used for the implementation. A part of the explanation may thus be that the agricultural practice is not as well defined and as homogeneous for all the other northern $\mathrm{Eu}-$ ropean countries as it is in Denmark where the agricultural practice is heavily controlled by the Danish legislation and local regulation (Skjøth et al., 2008). Another factor is the numbers used in Table 2, which have been derived from the RAINS system and distributed according to simple assumptions. As an example, then the RAINS system states a use of 88.3 kTonnes Urea ( $15 \%$ loss) and $941.7 \mathrm{k}$ Tonnes other fertilizers $(1.25 \%$ loss $)$ in the UK and $1.5 \%$ kTonnes Urea (15\% loss) and $250 \mathrm{k}$ Tonnes other fertilizers ( $2.14 \%$ loss) for Denmark respectively. Such factors results in significant differences in the distribution of the total ammonia emission related to each of the functions. Additionally, the contribution from crops is not included. This is clearly a weakness in the derived inventories as these emissions may be significant (Gyldenkærne et al., 2005).

Only a limited number of countries include emissions from crops in their national inventories. A better estimate than the default numbers in Table 2 is likely to be specific country based activity data with a higher spatial resolution as it is 
Table 4. Correlation coefficients observed mean and modelled bias between measured and modelled sum of $\mathrm{NH}_{3}$ and $\mathrm{NH}_{4}^{+}\left(\mathrm{NH}_{\mathrm{X}}\right)$ before and after implementation of the new dynamic $\mathrm{NH}_{3}$ emission inventory for northern Europe. Two steps have been used in the implementation of the new dynamic emission model. In the first step, data (new) from the RAINS model have been used to distribute the national emissions in each grid cell of the high resolution domain. In the second step (dk), the previously presented detailed Danish emission distribution on the 15 emission functions presented in Table 1 in (Skjøth et al., 2004; Skjøth et al., 2008) has been implemented as a supplement to the RAINS data. Calculations performed with the DEHM model for the year 2007.

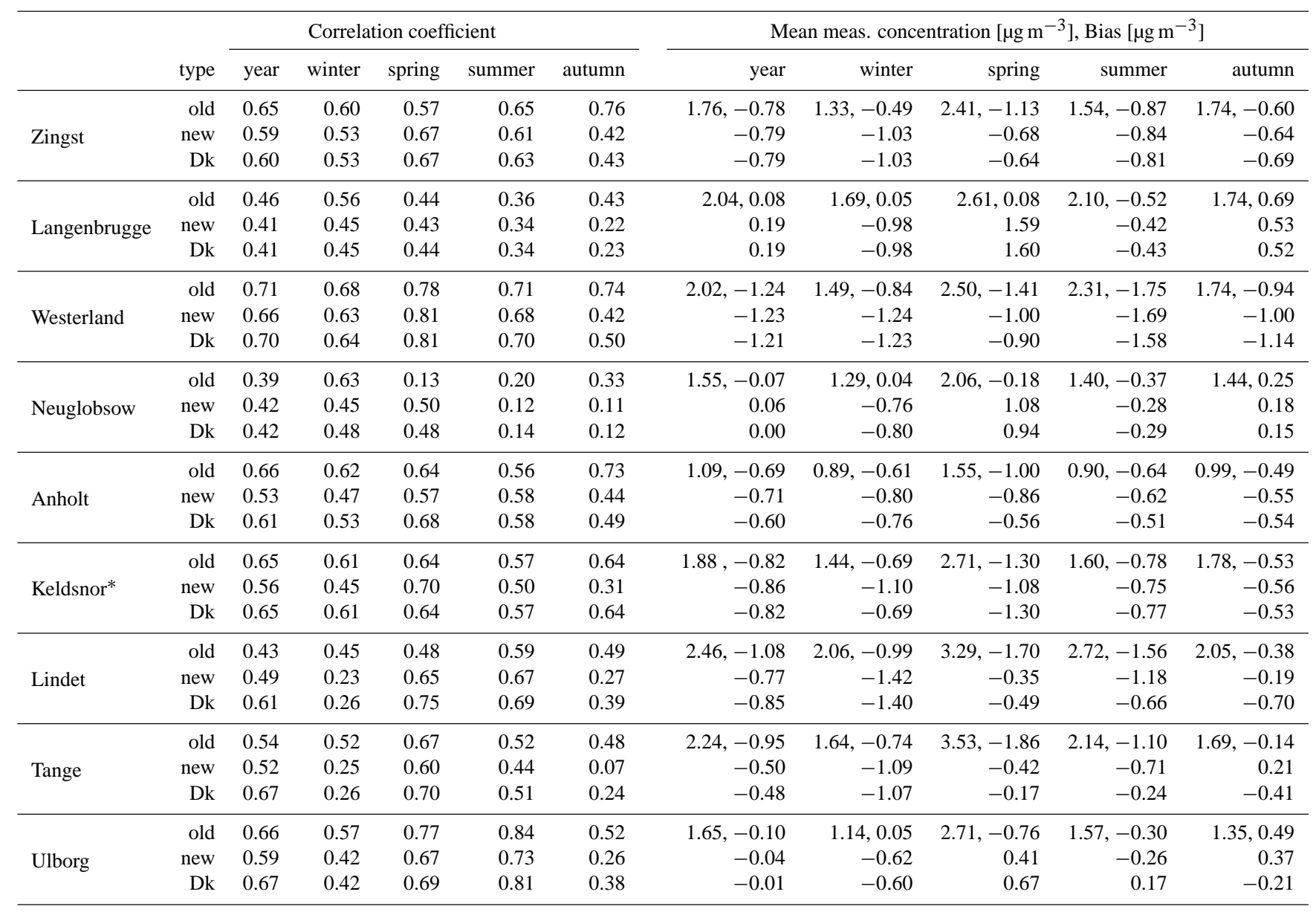

* At Keldsnor measured values from three days in October 2007 have been excluded here as they were unusual high and probably represented very local emissions.

shown in this paper for the Danish area. A third factor is the information about the exact location of the agricultural fields and more detailed information about the location, amount and type of livestock. As ammonia has a high deposition rate, knowledge on the location of large ammonia emitters in the vicinity of the monitoring stations and their temporal emission stations is essential. This would probably alter the emission strength and the emission pattern for e.g. the German stations Zingst and Westerland where a large part of the grid is water. This kind of data was available for the Danish area. Data of similar detail cannot currently be obtained for other countries. Data of similar detail are likely to exist in other countries, such as the Netherlands (e.g. Van Pul et al., 2008) and the UK (e.g. Hellsten et al., 2008), but are publicly not available due to confidentiality issues. However, there may be some possibilities in analyses of satellite images and in use of international or national statistical data concerning agricultural holdings like for the UK (Hellsten et al., 2008) or Poland (Kryza et al., 2011).

The dynamic temporal distribution model used in this paper showed a good performance for the Danish area and a smaller improvement for the German stations. This can be attributed to the spatial and temporal resolution of the input data. The ammonia emission is known to be dependent on incident global radiation, temperature, precipitation and humidity (Sommer, 1997; Sommer et al., 2003). The two major challenges in a temporal parameterization are therefore firstly how well the annual emission reflects the 

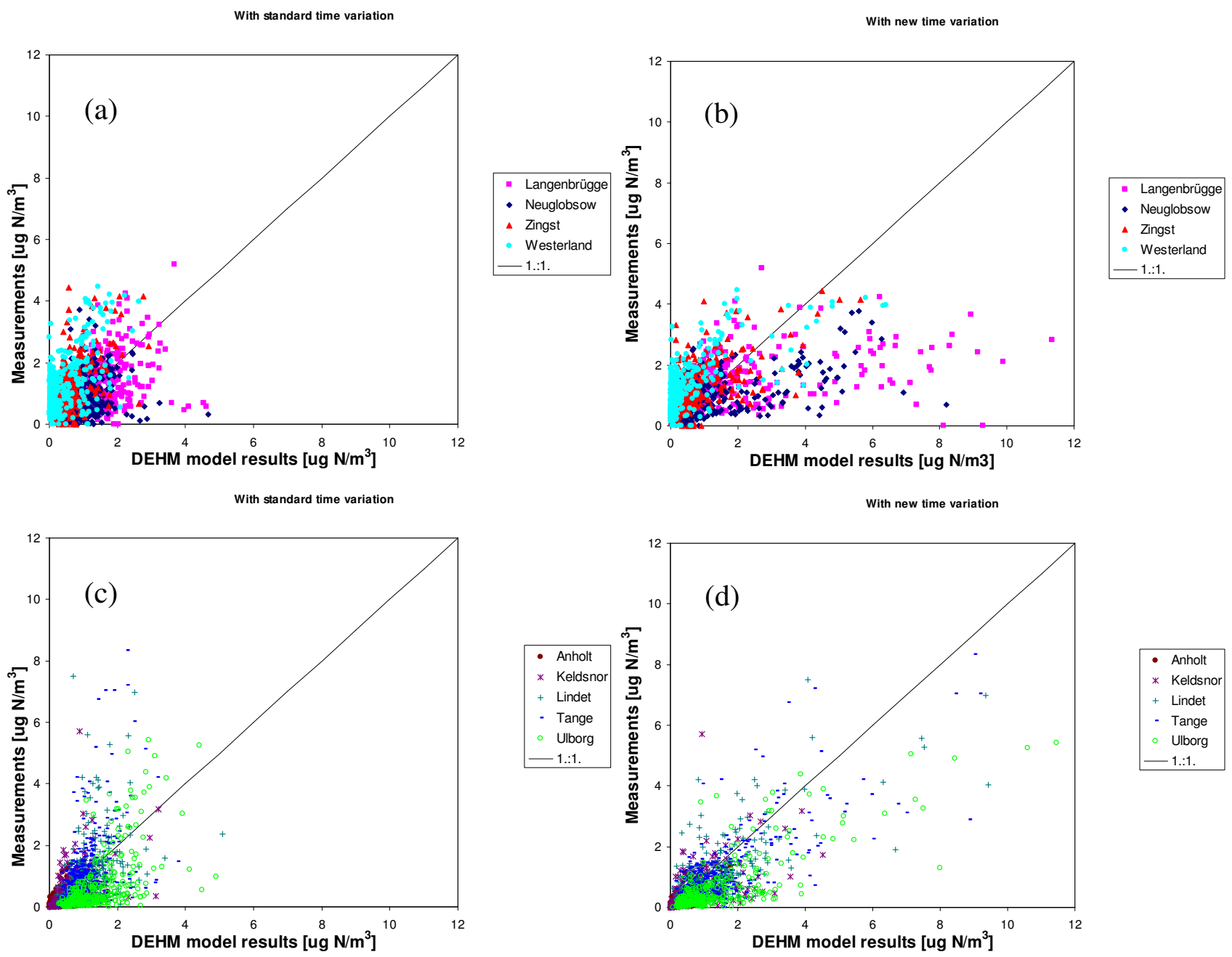

Fig. 11. Scatter plots between observed and modelled diurnal mean $\mathrm{NH}_{3}$ concentrations. All calculations are performed with the DEHM model and using both the original and the new dynamic $\mathrm{NH}_{3}$ emission model for northern Europe. The results are divided in the Danish and German monitoring sites. (a) German stations using the original $\mathrm{NH}_{3}$ emission inventory (b) German stations using the new $\mathrm{NH}_{3}$ emission inventory (c) Danish stations using the original $\mathrm{NH}_{3}$ emission inventory (d) Danish stations using the new $\mathrm{NH}_{3}$ emission inventory.

real emission. As many national inventories are only using one single emission factor to represent different activities like manure application, which take place under very different climatic conditions the emission estimates may be biased. Secondly, how well do the climatic co-variables included in the temporal model describe the real emission strength? The model used here (Gyldenkærne et al., 2005) is based on simple temperature relations and no dependence on solar radiation, precipitation and humidity is implemented. Hellsten et al. (2008) distributed the annual emissions in the United Kingdom in months according to farming activities to estimate "Emission potentials" and compared the monthly emission $\left(\mathrm{kg} \mathrm{Nha}^{-1}\right)$ with measured ammonia concentrations in the air $\left(\mu \mathrm{g} \mathrm{N} \mathrm{m}^{3}\right)$. The UK data has a high spatial resolution of $5 \times 5 \mathrm{~km}^{2}$ which feeds directly into high resolution CTM models like the FRAME and EMEP4UK models (Sin- gles et al., 1998; Vieno et al., 2010a, b). However, no climatic co-drivers were included in the temporal distribution of the ammonia emissions that feed into these models. The results from Hellsten et al. (2008) as well as more detailed process based studies (e.g. Sommer, 1997; Sommer et al., 2003) suggest that temperature effects should be taken into account when the emission estimates are used in chemical atmospheric transport models.

Precipitation events may in some cases make it impossible for the farmer to drive on the fields, and this can thereby delay the manure application in spring time for up to a couple of weeks. Naturally, the simple growth model, which is applied for determination of the timing of the manure application in spring, cannot capture this situation. Precipitation events have been found to explain an offset which has been observed for certain years in the timing of the manure application in 
Denmark. There are several possible ways that this type of information could be obtained and accounted for in the modelling: it could be done by reporting from the local farmers, but alternatively satellite observations might also be a way to determine the exact timing of the manure application periods in spring.

It is well-known that the split between gas phase $\mathrm{NH}_{3}$ and aerosol phase $\mathrm{NH}_{4}^{+}$may not be correct when filter pack measurements like those under the EMEP measurement programme are performed. The sum of the two compounds, the $\mathrm{NH}_{\mathrm{x}}$, is generally considered considerably more robust. Comparisons to denuder measurements have shown that for Danish conditions this split is well determined (Andersen and Hovmand, 1994), but for other EMEP sites this is a major uncertainty in the validation and the explanation for also performing comparisons between model calculations and measurements of $\mathrm{NH}_{\mathrm{x}}$. Here it is interesting to see, that the dynamical $\mathrm{NH}_{3}$ emission model improves the results at all the investigated sites, and that the improvements are not reflected to a similar degree in the $\mathrm{NH}_{\mathrm{x}}$ concentrations at the same sites. The reason with these limited improvements for $\mathrm{NH}_{\mathrm{x}}$ concentrations remains unexplained as it can be related to limitations of the applied emission inventory (assumptions or geographical coverage), uncertainties in the CTM model concerning the chemical scheme and particle formation or uncertainties related to grid resolution or the meteorological input. This suggests additional studies with CTM models with focus on ammonia and its transformation into ammonium including factors that affects this transformation.

The dynamic emission model may be applied with or without scaling of the emissions to officially reported values on annual basis. In the present study emissions are scaled country wise to the national total annual $\mathrm{NH}_{3}$ emissions reported to EMEP. However, when scaling is omitted, the dynamic emission model may be used to account for inter-annual variations resulting from the variations in meteorological conditions; inter-annual variations that most likely are not accounted for in the values reported by the various countries to EMEP. This provides the basis for estimating the impact of climate change on $\mathrm{NH}_{3}$ which again will affect important issues like e.g. atmospheric $\mathrm{N}$ deposition to marine waters that are under high nutrient pressure like the Baltic Sea (Hertel et al., 2003), the impact of future climate on the atmospheric nitrogen loads to the Baltic waters remain an issue that is considered an open question (Langner et al., 2009). Another even more important issue is the loading of sensitive terrestrial ecosystems that often receive large local contributions to the nitrogen loadings from local agricultural sources (Hertel et al., 2006).

\section{Conclusions}

We present here a model code for calculating ammonia emission on European scale. The model code is freely available and flexible for use with respect to geographical area and underlying assumptions. The model results are limited by amount and quality of input data but the presented work has demonstrated that even with scarce and rather uncertain information about agricultural practice and production methods, improvements in CTM modelling may be obtained from applying a dynamic $\mathrm{NH}_{3}$ emission model. The performance is very good for Denmark where highly detailed data of high quality is available whereas the performance improvements are considerable in the first application for northern to central Europe presented in the present paper. This suggest additional experiments with the emission model, especially in well studied areas like the UK where detailed inventories are available (Dragosits et al., 1998; Sutton et al., 2000) as well as surveys of farming practice (Hellsten et al., 2008). Better performance is foreseen when more detailed and more precise information is available in a near future.

\section{Perspectives and further work}

It is outside the scope of this paper to provide a large number of CTM calculations after the implementation of the dynamic emission model for the northern European region. More detailed studies are therefore planned including an implementation in both the DEHM and the EMEP models in order to test model differences as well as the effect on the calculations of other chemical species. It is also possible to test the implementation of the dynamic emission model with more detailed data than what has been available for this work.

The presented implementation of the dynamic model is based on country wise distributions between the agricultural emission categories $\left(\mathrm{Fkt}_{1}-\mathrm{Fkt}_{15}\right)$. However, even for Denmark large differences in agricultural activities are seen across the country, this is especially the case with respect to animal households (most of the animal production in Denmark takes place in the western parts of the country). Inclusion of data on sub-national level to account for variations in agricultural activities within the countries will therefore be a focal point in the further development and implementation of the dynamic emission model. Some of the sub-national level data are likely to be obtained from EUROSTAT which holds some information about animal households, crops and location of fields on sub-national level. More detailed information about animal households will also improve the inventory in relation to use of mineral fertiliser since this is used as supplement to manure application to ensure the needs of the crops on the fields. Another area that calls for improvements in comparison to the presented implementation is the information about local manure storage capacity. This type of information has not been used in the presented study, but it is valuable information in relation to determining the timing of manure application. 


\section{Supplementary material related to this article is available online at: http://www.atmos-chem-phys.net/11/5221/2011/ acp-11-5221-2011-supplement.zip.}

Acknowledgements. This work received funding from a grant provided by the Nordic Council of Ministers, from research funds under the Baltic Nest Institute, and from a post doc grant (to Carsten Ambelas Skjøth) provided by the Villum Kann Rasmussen foundation.

Edited by: A. B. Guenther

\section{References}

Andersen, H. V. and Hovmand, M. F.: Measurements of Ammonia and Ammonium by Denuder and Filter Pack, Atmos. Environ., 28, 3495-3512, 1994.

Anderson, N., Strader, R., and Davidson, C.: Airborne reduced nitrogen: ammonia emissions from agriculture and other sources, Environ. Int., 29, 277-286, 2003.

Barbu, A. L., Segers, A. J., Schaap, M., Heemink, A. W., and Builtjes, P. J. H.: A multi-component data assimilation experiment directed to sulphur dioxide and sulphate over Europe, Atmos. Environ., 43, 1622-1631, 2009.

Bouwman, A. F., Lee, D. S., Asman, W. A. H., Dentener, F. J., Van der Hoek, K. W., and Olivier, J. G. J.: A global high-resolution emission inventory for ammonia, Global Biogeochem. Cy., 11, 561-587, 1997.

Christensen, J. H.: The Danish Eulerian hemispheric model - A three-dimensional air pollution model used for the Arctic, Atmos. Environ., 31, 4169-4191, 1997.

de Meij, A., Krol, M., Dentener, F., Vignati, E., Cuvelier, C., and Thunis, P.: The sensitivity of aerosol in Europe to two different emission inventories and temporal distribution of emissions, Atmos. Chem. Phys., 6, 4287-4309, doi:10.5194/acp-6-4287-2006, 2006.

de Meij, A., Thunis, P., Bessagnet, B., and Cuvelier, C.: The sensitivity of the CHIMERE model to emissions reduction scenarios on air quality in Northern Italy, Atmos. Environ., 43, 1897-1907, 2009.

Dragosits, U., Sutton, M. A., Place, C. J., and Bayley, A. A.: Modelling the spatial distribution of agricultural ammonia emissions in the UK, Environ. Pollut., 102, 195-203, 1998.

Ellermann, T., Bossi, R., Christensen, J, Geels, C., Kemp, K., Løfstrøm, P., Mogensen, B. B., and Monies, C.: Atmospheric deposition 2007 NOVANA (In Danish: Atmosfærisk deposition 2007 NOVANA) : National Environmental Research Institute, Aarhus University, 97 pp., 2009.

Elzing, A. and Monteny, G. J.: Ammonia emission in a scale model of a dairy-cow house, T. Asae, 40, 713-720, 1997.

Fagerli, H. and Aas, W.: Trends of nitrogen in air and precipitation: Model results and observations at EMEP sites in Europe, 19802003, Environ. Pollut., 154, 448-461, 2008.

Frohn, L. M., Christensen, J. H., and Brandt, J.: Development of a high-resolution nested air pollution model - The numerical approach, J. Comput. Phys., 179, 68-94, 2002.
Gilliland, A. B., Dennis, R. L., Roselle, S. J., and Pierce, T. E.: Seasonal $\mathrm{NH}_{3}$ emission estimates for the eastern United States based on ammonium wet concentrations and an inverse modeling method, J. Geophys. Res., 108(D15), 4477, doi:10.1029/2002JD003063, 2003.

Grell, G. A., Dudhia, J., and Stauffer, D. R.: A description of the fifth-generation Penn State/NCAR mesoscale model (MM5), 1994.

Gyldenkærne, S., Ambelas Skjøth, C., Hertel, O., and Ellermann, T.: A dynamical ammonia emission parameterization for use in air pollution models, J. Geophys. Res., 110, D07108, doi:10.1029/2004JD005459, 2005.

Hellsten, S., Dragosits, U., Place, C. J., Vieno, M., Dore, A. J., Misselbrook, T. H., Tang, Y. S., and Sutton, M. A.: Modelling the spatial distribution of ammonia emissions in the UK, Environ. Pollut., 154, 370-379, 2008.

Hertel, O., Skjøth, C. A., Frohn, L. M., Vignati, E., Frydendall, J., de Leeuw, G., Schwarz, U., and Reis, S.: Assessment of the atmospheric nitrogen and sulphur inputs into the North Sea using a Lagrangian model, Phys. Chem. Earth, 27, 1507-1515, 2002.

Hertel, O., Ambelas Skjøth, C., Brandt, J., Christensen, J. H., Frohn, L. M., and Frydendall, J.: Operational mapping of atmospheric nitrogen deposition to the Baltic Sea, Atmos. Chem. Phys., 3, 2083-2099, doi:10.5194/acp-3-2083-2003, 2003.

Hertel, O., Skjøth, C. A., Løfstrøm, P., Geels, C., Frohn, L. M., Ellermann, T., and Madsen, P. V.: Modelling Nitrogen Deposition on a Local Scale - A Review of the Current State of the Art, Environ. Chem., 3, 317-337, 2006.

Hutchings, N. J., Sommer, S. G., Andersen, J. M., and Asman, W. A. H.: A detailed ammonia emission inventory for Denmark, Atmos. Environ., 35, 1959-1968, 2001.

Klimont, Z. and Brink, C.: Modelling of Emissions of Air Pollutants and Greenhouse Gases from Agricultural Sources in Europe : International Institute for Applied Systems Analysis (IIASA), Laxenburg, Autria, 69 pp., 1-9-2004.

Kryza, M., Dore, A. J., Blas, M., and Sobik, M.: Modelling deposition and air concentration of reduced nitrogen in Poland and sensitivity to variability in annual meteorology, J. Environ. Manage., 92, 1225-1236, 2011.

Langner, J., Andersson, C., and Engardt, M.: Atmospheric input of nitrogen to the Baltic Sea basin: present situation, variability due to meteorology and impact of climate change, Boreal Environ. Res., 14, 226-237, 2009.

Menut, L. and Bessagnet, B.: Atmospheric composition forecasting in Europe, Ann. Geophys., 28, 61-74, 2010.

Olesen, J. E. and Plauborg, F.: MVTOOL version 1.10 for developing MARKVAND : Danish Institute of Plant and Soil Sciences, 64 pp., 1995.

Pinder, R. W., Adams, P. J., Pandis, S. N., and Gilliland, A. B.: Temporally resolved ammonia emission inventories: Current estimates, evaluation tools, and measurement needs, J. Geophys. Res., 111, D16310, doi:10.1029/2005JD006603, 2006.

Pul, A. v., Jaarsveld, H. V., Meulen, T. v. d., and Velders, G.: Ammonia concentrations in the Netherlands: spatially detailed measurements and model calculations, Atmos. Environ., 38, 40454055, 2004.

Reis, S., Pinder, R. W., Zhang, M., Lijie, G., and Sutton, M. A.: Reactive nitrogen in atmospheric emission inventories, Atmos. Chem. Phys., 9, 7657-7677, doi:10.5194/acp-9-7657-2009, 
2009.

Seedorf, J., Hartung, J., Schroder, M., Linkert, K. H., Pedersen, S., Takai, H., Johnsen, J. O., Metz, J. H. M., Groot Koerkamp, P. W. G., and Uenk, G. H.: A Survey of Ventilation Rates in Livestock Buildings in Northern Europe, J. Agr. Eng. Res., 70, 39-47, 1998a.

Seedorf, J., Hartung, J., Schroder, M., Linkert, K. H., Pedersen, S., Takai, H., Johnsen, J. O., Metz, J. H. M., Groot Koerkamp, P. W. G., and Uenk, G. H.: Temperature and Moisture Conditions in Livestock Buildings in Northern Europe, J. Agr. Eng. Res., 70, 49-57, 1998b.

Singles, R., Sutton, M. A., and Weston, K. J.: A multi-layer model to describe the atmospheric transport and deposition of ammonia in Great Britain, Atmos. Environ., 32, 393-399, 1998.

Skjøth, C. A., Hertel, O., Gyldenkærne, S., and Ellerman, T.: Implementing a dynamical ammonia emission parameterization in the large-scale air pollution model ACDEP, J. Geophys. Res., 109, D06306, doi:10.1029/2003JD003895, 2004.

Skjøth, C. A., Ellermann, T., Hertel, O., Gyldenkærne, S., and Mikkelsen, M. H.: Footprints on ammonia concentrations from environmental regulations, J. Air Waste Manage., 58, 11581165, 2008.

Sommer, S. G.: Ammonia volatilization from farm tanks containing anaerobically digested animal slurry, Atmos. Environ., 31, 863868, 1997.

Sommer, S. G., Genermont, S., Cellier, P., Hutchings, N. J., Olesen, J. E., and Morvan, T.: Processes controlling ammonia emission from livestock slurry in the field, Eur. J. Agron., 19, 465-486, 2003.

Sutton, M. A., Dragosits, U., Tang, Y. S., and Fowler, D.: Ammonia emissions from non-agricultural sources in the UK, Atmos. Environ., 34, 855-869, 2000.
Sutton, M. A., Nemitz, E., Theobald, M. R., Milford, C., Dorsey, J. R., Gallagher, M. W., Hensen, A., Jongejan, P. A. C., Erisman, J. W., Mattsson, M., Schjoerring, J. K., Cellier, P., Loubet, B., Roche, R., Neftel, A., Hermann, B., Jones, S. K., Lehman, B. E., Horvath, L., Weidinger, T., Rajkai, K., Burkhardt, J., Löpmeier, F. J., and Daemmgen, U.: Dynamics of ammonia exchange with cut grassland: strategy and implementation of the GRAMINAE Integrated Experiment, Biogeosciences, 6, 309331, doi:10.5194/bg-6-309-2009, 2009.

Theobald, M. R., Bealey, W. J., Tang, Y. S., Vallejo, A., and Sutton, M. A.: A simple model for screening the local impacts of atmospheric ammonia, Sci. Total Environ., 407, 6024-6033, 2009.

Van Pul, W. A. J., Van Jaarsveld, J. A., Vellinga, O. S., van den Broek, M., and Smits, M. C. J.: The VELD experiment: An evaluation of the ammonia emissions and concentrations in an agricultural area, Atmos. Environ., 42, 8086-8095, 2008.

Vieno, M., Dore, A. J., Bealey, W. J., Stevenson, D. S., and Sutton, M. A.: The importance of source configuration in quantifying footprints of regional atmospheric sulphur deposition, Sci. Total Environ., 408, 985-995, 2010a.

Vieno, M., Dore, A. J., Stevenson, D. S., Doherty, R., Heal, M. R., Reis, S., Hallsworth, S., Tarrason, L., Wind, P., Fowler, D., Simpson, D., and Sutton, M. A.: Modelling surface ozone during the 2003 heat-wave in the UK, Atmos. Chem. Phys., 10, 79637978, doi:10.5194/acp-10-7963-2010, 2010b.

Zhang, Y., Wu, S. Y., Krishnan, S., Wang, K., Queen, A., Aneja, V. P., and Arya, S. P.: Modeling agricultural air quality: Current status, major challenges, and outlook, Atmos. Environ., 42, 3218-3237, 2008. 